\title{
TRANSFORMAÇÕES NA INSTÂNCIA DA RECEPÇÃO: A CONSTRUÇÃO DO LEITOR COPRODUTOR EM REDES SOCIAIS DIGITAIS
}

\author{
Transformations of reception: the construction of the coprodutor reader in \\ digital social networks
}

\author{
Cambios en la recepcion: la construcción del lector coprodutor em redes \\ sociales digitales
}

Carlos Sanchotene

Professor de Jornalismo e Publicidade e Propaganda da UEMG carlos_sanchotene@yahoo.com.br

\begin{abstract}
Resumo
Objetivamos compreender a construção do leitor coprodutor no contexto do jornalismo em redes sociais digitais. Para tanto, faremos uma retomada sobre a problemática da recepção para situarmos a transformação da posição do sujeito-receptor. A partir da percepção de que os receptores são ativos, a análise sobre a circulação passa a ser vista como o espaço do reconhecimento e de maiores possibilidades de ocorrência interacional, na prática social e de descobertas na investigação. Veremos como o avanço da tecnologia foi significativo para esse processo identificando distintos tipos de leitores. Por fim, concluímos que as redes sociais digitais possibilitaram a democratização das competências desses leitores que manejam com desenvoltura linguagens hipertextuais reconfigurando atos de leitura.
\end{abstract}

Palavras-chave: Leitor coprodutor. Recepção. Redes sociais digitais.

\begin{abstract}
We aim to understand the construction of the coproducer reader in the context of journalism in digital social networks. To do so, we will retake the problem of reception in order to situate the transformation of the subject-receiver position. From the perception that the receptors are active, the analysis of the circulation is seen as the space of recognition and of greater possibilities of interactional occurrence, in social practice and in research findings. We will see how the advancement of technology was significant for this process by identifying different types of readers. Finally, we conclude that digital social networks have made it possible to democratize the skills of these readers who are able to handle hypertextual languages by reconfiguring reading acts.
\end{abstract}

Key words: Coproducer reader. Reception. Digital social networks.

\section{Resumen}

El objetivo fue comprender la construcción del lector coproductor en el contexto del periodismo en las redes sociales digitales. Por lo tanto, vamos a reanudar en el tema de recepción para situar la transformación de la posición del sujeto-receptor. A partir de la 
constatación de que los receptores son activos, el análisis de la circulación es visto como el espacio de reconocimiento y de oportunidades de interacción, en la práctica social y descubrimientos en la investigación. Veremos cómo el avance de la tecnología fue significativo a este proceso mediante la identificación de los diferentes tipos de lectores. Por último, llegamos a la conclusión de que las redes sociales digitales hizo posible la democratización de las habilidades de aquellos lectores que manejan con aplomo idiomas hipertextuais reajustando actos de lectura.

Palabras clave: Lector coproductor. Recepción. Redes sociales digitales.

\section{INTRODUÇÃO}

A renovação da posição do receptor vem sendo estudada e debatida principalmente a partir da década de 80 quando autores ligados aos Estudos Culturais passaram a se interessar pelas audiências. Essa abordagem contrapõe-se à teoria hipodérmica do início do século XX, que tem como pressuposto a resposta do indivíduo às sugestões dos meios de comunicação, considerando a audiência como uma massa formada por indivíduos homogêneos, isolados, anônimos e atomizados.

A tradição da pesquisa em recepção iniciou com o Estudo dos Efeitos $^{1}$ de origem norte-americana onde os receptores deveriam ser persuadidos e, para isso, era necessário conhecer o efeito dos meios de comunicação de massa sobre esses indivíduos. Outra linha de investigação da recepção foi a análise das mensagens e dos produtores da indústria cultural que, a partir da concepção teórica da Escola de Frankfurt, acreditavam na passividade dos receptores e de sua manipulação pelos meios.

Na perspectiva dos Estudos Culturais, o receptor ganha mais poder, deixando de ser visto como um sujeito passivo e passando a ser entendido como alguém que ressignifica o que consome construindo sentidos. A comunicação passa a ser entendida como processo integrado às práticas sociais como um todo, estas entendidas como as que dão sentido à vida diária (JACKS; ESCOSTEGUY, 2005). Valorizam-se nesta linha os processos de produção de sentidos e as relações entre as práticas simbólicas e as estruturas de poder.

Uma versão dessa perspectiva de ver a comunicação vem sendo desenvolvida por autores latinos que pensam a comunicação como um processo frente a uma visão multidisciplinar adotada durante suas investigações no campo comunicacional. Atualmente,

\footnotetext{
${ }^{1}$ De acordo com esse modelo, uma mensagem produzida pelos meios de comunicação é imediatamente aceita e espalhada entre todos os receptores, em igual proporção. Na década de 1920, os conceitos foram elaborados pela Escola Norte-Americana com o objetivo de fornecer bases empíricas e científicas para a elaboração de sistemas de comunicação, com ênfase nos efeitos da comunicação sobre o comportamento da população.
} 
têm-se como referencial teórico os trabalhos experimentais metodológicos de Néstor García Canclini, Jesús Martín-Barbero, Guilhermo Orozco Gómez, German Rey, Maria Immacolata Vassalo de Lopes, Veneza Ronsini, Nilda Jacks, entre outros, especialmente acerca do popular e da cultura na comunicação.

A pesquisa no contexto latino-americano começa a ganhar força a partir da incorporação das proposições de Martín-Barbero, responsável pela obra "Dos meios às mediações”, originalmente lançada em 1987. Muda-se a abordagem, da análise do discurso dos meios à investigação das culturas populares e, o autor, preocupa-se em desvendar os modos comunicacionais desses setores, as relações estabelecidas entre o que é veiculado pelos meios massivos e o que passa nas ruas, nos bairros.

Por meio do modelo comunicacional de Martín-Barbero (2008) é possível estabelecer a recepção midiática como um processo de interação, pois entre polo emissor e receptor há espaço de natureza representativa ou simbólica, preenchido por experiência e complexidade de conteúdos que ditam os modos como a mensagem será absorvida pelo receptor.

A maioria dos estudos em recepção centraliza-se nas mediações que esse processo perpassa, ou seja, estuda-se o papel dos meios na vida cotidiana, a partir das singularidades culturais pertencentes a cada indivíduo ou comunidade. No entanto, "a recepção é então um contexto complexo, multidimensional em que as pessoas vivem o seu cotidiano" (LOPES, 2000, p. 125). E ainda, as práticas são articuladas por relações de poder que dão um sentido muito mais amplo do que o significado propriamente produzido ou reproduzido dentro dos processos culturais.

De acordo com Jacks e Schmitz (2018, p.117) a diferenciação entre o massivo e o popular realizada por Martín-Barbero evidencia que os meios de comunicação "são espaços que podem ser sobrepostos, inter-relacionados, ou não, dependendo dos usos dados pelos receptores". Ou seja, o mundo social e cultural são vistos como instituições sociais que ressignificam sentidos.

Para Ronsini (2010) a ênfase da recepção reside na análise da constituição do cultural pelas mediações comunicativas, pois as mediações que atravessam a relação dos receptores com os meios não existem fora da relação com os meios. "As mediações comunicativas na recepção são apreendidas através da análise dos textos midiáticos relevantes no cotidiano do receptor, abrangendo o exame do texto e dos usos, da sua circulação no espaço/tempo do receptor e da conformação deste espaço/tempo" (RONSINI, 2010, p.11). Nesse sentido, a autora defende que a apreensão da totalidade do fenômeno da recepção deve se dar a partir de 
um projeto que busca estudar as relações entre mídia, sociedade e cultura. Só assim, é possível avançar tanto nas relações culturais instauradas pelos meios técnicos como no entendimento das relações sociais mediadas pelos meios de comunicação.

Diante dessa conjuntura buscamos compreender o lugar da recepção e o tipo de leitor que emerge no contexto do jornalismo em redes sociais digitais. A análise sobre a circulação passa a ser vista como o espaço do reconhecimento e de maiores possibilidades de ocorrência interacional, na prática social e de descobertas na investigação. Ao longo desse texto, veremos como o avanço das tecnologias digitais foi importante para esse processo identificando distintos tipos de leitores.

\section{2 “RECEPÇÃO” EM MOVIMENTO}

O avanço da tecnologia aliada à comunicação e cultura fez Martín-Barbero repensar sua noção de mediação, por exemplo, afirmando que "a investigação agora já não será sobre as matrizes culturais da comunicação, mas sobre as matrizes comunicativas da cultura" (MARTÍN-BARBERO, 2009, p. 14). Desse modo, a reflexão que outrora investigava "dos meios às mediações" inverte-se para "das mediações aos meios".

No primeiro modelo, desenvolvido inicialmente em 1987, o meio não é fator central, pois a cotidianidade familiar, a temporalidade social e a competência cultural eram consideradas as matrizes culturais da comunicação. Com a rápida transformação dos meios surge o mapa ${ }^{2}$ das mediações comunicativas da cultura.

[...] estamos ante uma interação que desestabiliza os discursos próprios de cada meio. Então estamos ante formas mestiças que começam a ser produzidas, formas incoerentes porque rompem a norma atuando transversalmente em todos os meios. Não é uma coisa racional como a intertextualidade que está sob o que foi escrito, que é tudo o que foi lido. É a contaminação entre sonoridades, textualidades, visualidades, as matériasprimas dos gêneros (MARTíN-BARBERO, 2009, p.13).

Segundo o autor, confundir a comunicação com as técnicas e com os meios é tão deformador como pensar que os mesmos sejam exteriores à comunicação, pois a afetação é mútua. Para Martín-Barbero (2008), a centralidade dos meios deve ser questionada justamente

\footnotetext{
${ }^{2}$ A nova forma de compreensão mostra relações constitutivas entre comunicação, cultura e política, expressadas por um eixo sincrônico e outro diacrônico. No último mapa a relação se dá entre Matrizes Culturais (MC) e Formatos Industriais (FI), e, no anterior, entre Lógicas de Produção (LP) e Competências de Recepção ou Consumo (CR).
} 
diante da sua tomada por atores sociais, pois, atualmente, vê-se o meio não mais limitado a vincular ou a traduzir as representações existentes, nem mesmo substituí-las, mas sim constituindo uma cena fundamental na vida pública, onde as práticas sociais se fazem no meio e pelo meio.

Nesse cenário, o autor trata da "intermedialidade", um conceito para pensar a hibridação das linguagens e dos meios apontando para os modos como a tecnologia pode moldar a cultura e as práticas sociais. Assim, o autor avança ao tratar da mediação "tecnicidade" como a capacidade de inovação dos formatos industriais e das formas de receber mensagens midiáticas: “a estratégica mediação da tecnicidade se delineia atualmente em um novo cenário [...] não só no espaço das redes informáticas como também na conexão dos meios - televisão e telefone - com o computador" (MARTÍN-BARBERO, 2008, p. 19).

Pieniz (2013) ao estudar a reconfiguração dos modos de ser audiência de telenovela, a partir da análise do Twitter, sob a visão dos estudos de recepção, afirma que a intenção de Martín-Barbero, ao trabalhar a tecnicidade, parece ser a de dar conta de expressar melhor a realidade comunicacional do momento, não demarcando radicalmente os pólos de emissão e recepção. Os grandes elementos são: tempo, espaço, migrações, fluxos. Assim, as mediações passam a ser o locus para entender as transformações do tempo e do espaço a partir de migrações e fluxos de imagens (MARTÍN-BARBERO, 2009).

Segundo Pieniz (2013), a tecnicidade adquiriu diversas formas ao longo do desenvolvimento das condições comunicacionais de cada tempo. Contemporaneamente, é percebida com mais impacto pelo processo de midiatização alavancado pela convergência que permite esta situação de trânsito para as mutações culturais.

Este trânsito, por sua vez, permite a constituição de identidades emergentes e formas de cognitividades, articulando as mediações comunicativas da cultura às mediações pensadas para as mutações culturais, onde a ritualidade e a tecnicidade permanecem. Há novas identidades e novas cognitividades neste cenário de fluxos e migrações, com mutações no tempo e espaço (PIENIZ, 2013, p.46).

Sendo assim, a tecnicidade não pode ser compreendida como totalizante ou a mais importante, visto que há outras, além das tecnologias. Scolari (2008, p.113), por exemplo, define "hipermediação" como "um processo de intercâmbio, produção, e consumo que se desenvolvem em um entorno caracterizados por uma grande quantidade de sujeitos, meios e linguagens interconectados tecnologicamente de maneira reticular entre si”. A expansão desse 
processo produtivo integrado evidencia que a convergência dos meios conduz a multimidialidade textual (áudio, fotos, vídeos, animações, texto escrito, etc.) somada à interatividade em rede e se converte nas hipermediações.

Martín-Barbero (2008), nesse contexto, afirma que existem possibilidades de novos usos sociais dos meios, que propiciam a formação de novas esferas do público, com novas formas de imaginação e criatividade social. Assim, corroboramos com Scolari (2008) quando o autor afirma que as redes sociais digitais são a manifestação mais clara dos processos de troca que caracterizariam essa trama de significações, trocas, produção e linguagens que emprestam seus contornos e seus fenômenos a essa tal hipermodernidade e, mais, ao sujeito hipermediado que dela parece resultar. Segundo o pesquisador, o espaço hipermediado onde esse sujeito parece transitar, o mesmo espaço compartilhado por outros iguais - um espaço no qual as redes sociais digitais desempenham um significativo intercâmbio informativo/tecnológico/ comunicacional -, é tal qual um "buraco negro que atrai, absorve e integra" (SCOLARI, 2008, p. 277).

Nesse sentido, o contexto atual traz mudanças na forma de ver e entender as audiências. A presença dos dispositivos comunicacionais no tecido social fez com que o esquema comunicativo baseado em um único sentido (emissor - receptor) se reconfigurasse para redes múltiplas nas quais cada indivíduo é um ponto de início e chegada da cadeia de interações. Com isso, surgem várias denominações que marcam a diferença entre velhos e novos meios, sendo a audiência, um fator que aqui nos interessa.

O termo audiência, por exemplo, encontra-se ultrapassado pois carrega uma ideia de público passivo que apenas recebe determinada mensagem dos meios de comunicação. $\mathrm{O}$ mesmo acontece com o termo "consumidor", pois faz referência a indivíduos que recebem mensagem de outros grupos que são produtores e encontram-se numa posição de superioridade. Alejandro Re (2014) ao estudar o debate político na cultura da convergência e as características dos usuários nas redes sociais digitais, propõe o conceito de "usuários de meios" como um princípio mais geral de entendimento.

[...] ao dizer "usuário", e não "consumidor" ou "audiência", estamos descrevendo da melhor forma a principal ação que levam a cabo os cidadãos quando acessam um meio de comunicação: usam. Seja para gerar uma conversa com outros, para adotar uma posição ideológica, para participar de debates na web ou para gerar seus próprios conteúdos, entre muitas outras 
opções, o fim do acesso aos meios é, tal como explica Lash, puramente utilitário ${ }^{3}$ (RE, 2014, p.41, tradução nossa).

Scolari (2008), contudo, considera pejorativa a noção de usuário porque denota uma relação parasitária com a tecnologia. Para o autor, diferente do operador, o usuário desconhece o funcionamento dos dispositivos que usa cotidianamente. "Esta imagem do usuário como sujeito passivo, à mercê das inevitáveis ondas digitais, é a princípio compartilhada tanto por filósofos ciberutópicos como por apocalípticos da tecnologia ${ }^{4 "}$ (SCOLARI, 2008, p.260, tradução nossa).

Nesse sentido, Maestri (2010) considera pertinente falar de hiperaudiências, ou seja, aquela audiência interconectada e com habilidades comunicativas adquiridas no ambiente midiatizado. Apesar de um conceito muito raso, a autora defende que essa audiência está integrada por sujeitos com comportamentos migratórios, capazes de perambular por distintos dispositivos tecnológicos. "A ideia de hiperaudiência tenta descobrir este momento da recepção em que os sujeitos não apenas consomem mas também utilizam as novas tecnologias interativas para gerar novos conteúdos e cooperar com outros sujeitos ${ }^{5}$ " (MAESTRI, 2010, p. 129, tradução nossa). Assim, lista as principais características da hiperaudiência, como: feedback contínuo - instantaneidade; interatividade; mudança do real para o virtual; produção de cada sujeito; flexibilidade no uso de diferentes meios, ao mesmo tempo; trocas "muitosmuitos" (MAESTRI, 2010).

Natansohn (2007) ao refletir sobre a recepção na web faz duas observações. A primeira é que quando se fala de audiências de jornalismo é preciso não cair na armadilha de pensar na demanda do público como algo desvinculado da oferta. A resposta frequente à questão sobre o que querem as audiências, normalmente é formulada em termos de quais as reações dos usuários à oferta de conteúdos e serviços. A autora explica que as formas de propriedade dominante do jornalismo (comercial e vinculado a grandes empresas) justificam tais formas de tratar da audiência e o consumo, já que refere-se a um produto cujo objetivo é ser consumido pela maior quantidade de pessoas. A segunda é que não foi fácil pesquisar as

\footnotetext{
${ }^{3}$ Texto original: "[...] al decir "usuario", y no "consumidor" o "audiencia", estamos describiendo de mejor forma la principal acción que llevan a cabo los ciudadanos cuando acceden a un medio de comunicación: lo usan. Ya sea para generar una charla con otros, para adoptar una posición ideológica, para participar de debates en la web o para generar sus propios contenidos, entre muchas otras opciones, el fin del acceso a los médios es, tal y como explica Lash, puramente utilitário" (RE, 2014, p.41).

${ }^{4}$ Texto original: "Esta imagen del usuario como sujeto pasivo, a merced de las inevitables olas digitales, es a menudo compartida tanto por los filósofos ciberutópicos como por los apocalípticos de lo tecnológico" (SCOLARI, 2008, p.260).

${ }^{5}$ Texto original: "La idea de hiperaudiencia intenta describir este momento de la recepción en la que los sujetos no sólo consumen sino que además utilizan las nuevas tecnologías interactivas para generar nuevos contenidos y cooperar con otros sujetos" (MAESTRI, 2010, p. 219).
} 
questões tecnológicas dentro do campo das teorias críticas e culturalistas. "O debate sobre a tecnologia sofreu, até entrados os 90, de acusações fortemente ideologizadas, que denunciavam os efeitos homogeneizadores da tecnologia eletrônica" (NATANSOHN, 2007, p.11). É a partir dos anos 90 que esta situação começa a mudar.

De acordo com a autora, na web a produção de sentido vai além da pura atividade interna, pois adquire uma materialidade diferencial, seja porque há um registro material da leitura ou porque além de receptor, o sujeito pode alimentar o circuito comunicacional por meio de um fazer concreto como: enviar mensagens, propor pautas, comentar notícias, ser fonte de notícias, etc. Assim, questiona o interesse dos estudos culturais de recepção, perante uma tecnologia como a internet como suporte para a informação. Natansohn (2007) vai afirmar que a pesquisa em novas mídias pode reconstituir a articulação entre os microprocessos de interação para a evolução das gramáticas de interação, em contextos de uso.

"A análise da instância de produção na web se complica tanto pela dinamicidade quanto pela liquidez dos processos de interação [...] Longe de ser uma atividade automática, natural e transparente, a interação com as máquinas, com os outros e com os produtos se dá através das interfaces" (NATANSOHN, 2007, p.13). A interface é vista pela autora como uma "gramática da interação" entre humanos e computadores e é um produto de um sujeito desenhista. No caso de mídia web, a relação será determinada: pelo tipo de interface gráfica; pelo sistema operacional; pelo sistema de publicação definido pela instituição jornalística; pela arquitetura da informação, seu desenho e as opções de navegação e interação predefinidas (produção de pautas, fóruns, chats, comentários, blogs, recursos multimídia, de memória, de personalização).

No entanto, a relação do usuário com a interface vai depender do tipo de conexão com a rede, do dispositivo através do qual acessa um determinado site (computador doméstico ou portátil, celular, agenda eletrônica, etc.), tudo isso atuando no processo de interação. "Tudo isso é o que vai determinar a gramática da interação, isto é, os dispositivos e as regras que regulam a interação possível” (NATANSOHN, 2007, p.13).

Em nosso contexto, utilizamos o termo leitor coprodutor para designar os indivíduos que estão nas redes sociais digitais interagindo, produzindo ou compartilhando conteúdos provindos de seus contatos e dispositivos com os quais interage. Para Scolari (2008), essa mudança semântica situa-se junto a evolução da internet. Inicialmente, passou de ser um sistema baseado no modelo broadcasting em que o consumo se realizava de forma individual 
e a difusão da produção era constituída por meio de uma relação "um-todos", e converte-se para a web 2.0, em que conteúdos e usuários estão entrelaçados e as comunidades de participação passam ao primeiro plano. Segundo o autor, o simples fato de consultar algo em um buscador implica uma produção de informação por parte do usuário, já que o sistema recupera, processa e utiliza essa ação para enriquecer a experiência de outros navegantes. Assim, ao participar no controle dos conteúdos, o usuário passa a ser parte desse conteúdo.

\section{CIRCULAÇÃO E CIRCUITO COMO AVANÇO}

A circulação é aqui compreendida como resultado da defasagem entre lógicas de processos de produção e de recepção de mensagens (VERÓN, 2005). Frequentemente ela é pensada com referência ao processo que vai da emissão a recepção. Zago (2011) ao estudar o Twitter, propõe pensar a recirculação como uma subetapa posterior ao consumo. É quando o interagente se apropria do conteúdo jornalístico e o faz circular novamente a partir de suas próprias palavras. Segundo a autora, trata-se de uma extensão da fase da circulação, "que é retomada e continua após o consumo de informação pelo interagente, o qual pode utilizar espaços sociais diversos da internet [...] para divulgar o link para a notícia, recontar com suas palavras o acontecimento ou manifestar sua opinião sobre o ocorrido" (ZAGO, 2011, p.63).

Em 2006, Braga já havia constatado a existência de um terceiro subsistema - tão abrangente e complexo como a emissão e a recepção - denominando de sistema de sistema de resposta social o reconhecimento de que a sociedade atribui um sentido social às ações e produtos oriundos dos meios de comunicação. Trata-se de como se dá o processo de circulação daquilo que é consumido.

Neste subsistema não se trata de circulação de bens materiais de consumo, e sim de circulação de interesses, ou seja, o que interessa não é o que a mídia veicula, mas o que, tendo sido veiculado pela mídia, depois circula na sociedade. Braga (2006) afirma, portanto, que é possível compreender como a sociedade funciona midiaticamente não apenas concentrando sobre sua produção e recepção, mas através de estudos sobre os dispositivos e processos sociais que a sociedade desenvolve para tratar a sua própria mídia.

Refletir sobre esse processo nos leva a pensar que a convergência tecnológica instaurou uma nova plataforma de circulação, assentada em diversidades de técnicas e de dispositivo, alterando as configurações e relações dos campos de produção e de recepção. As noções sobre "contratos de leituras", operações com que as mídias moldavam formas de 
interação com os receptores, remodelam-se, da mesma forma. Suas novas regras passam a ser anunciadas publicamente para que os "receptores" possam saber como eles operam tais interações. Tais cenários implicam que as mídias desenvolvam enunciações pelas quais peçam ao leitor reconhecimento de seu trabalho, e possa também estabelecer regras com que definam as condições de reconhecimento dos seus usuários (FAUSTO NETO, 2009).

Nestas condições, Fausto Neto (2009) acredita que a compreensão do conceito de circulação deixa de ser associado à defasagem e passa a ser compreendida como "pontos de articulação" entre a esfera da produção e da recepção. Dessa forma, avança como um novo objeto sendo nomeada como dispositivo, "pois a circulação é transformada em lugar no qual produtores e receptores se encontram em "jogos complexos" de oferta e de reconhecimento" (FAUSTO NETO, 2009, p.10).

Para Braga (2012), a circulação é vista como um espaço de maiores possibilidades de ocorrência interacional, na prática social; e de descobertas, na investigação. A partir disso, observam-se os desenvolvimentos sobre a relação produção/recepção. Para além das relações diretas entre produtor e receptor, importa o fato de que este último faz seguir adiante as reações ao que recebe. Isso decorre não apenas da presença de novos meios, mas também de que os produtos circulantes da "mídia de massa" são retomados em outros ambientes, que ultrapassam a situação de recepção.

Esse "fluxo adiante" acontece em variadíssimas formas - desde a reposição do próprio produto para outros usuários (modificado ou não); à elaboração de comentários - que podem resultar em textos publicados ou em simples "conversa de bar" sobre um filme recém visto; a uma retomada de ideias para gerar outros produtos (em sintonia ou contraposição); a uma estimulação de debates, análises, polêmicas - em processo agonístico; a esforços de sistematização analítica ou estudos sobre o tipo de questão inicialmente exposta; passando ainda por outras e outras possibilidades, incluindo aí, naturalmente a circulação que se manifesta nas redes sociais (BRAGA, 2012, p.39-40).

A partir da visada do autor, percebemos que as interfaces sociais se encadeiam e se deslocam do modelo conversacional para um fluxo contínuo. Segundo Braga, já não é tão simples distinguir "pontos iniciais" e "pontos de chegada", produção e recepção como instâncias separadas. "O que, aliás, nos faz perceber que tal construção decorre mais de uma condição histórica específica (a fase de implantação dos meios de massa) do que de uma pretendida "natureza" do processo interacional - que, pela própria etimologia da palavra, enfatiza antes a indistinção de papeis do que uma especialização "por estrutura"” (BRAGA, 
2012, p.40). Ou seja, as diferentes ações e assimetrias devem ser relacionadas antes a cada tipo específico de interação, assim como a seus contextos significativos; e não a uma pretendida lógica diferencial no interagir. O autor adverte, no entanto, que no caso dos meios de massa é possível distinguir claramente essas duas posições - que devem ser assim estudadas segundo suas lógicas específicas; mas evitando naturalizar estes papéis como se fossem categorias inelutáveis da midiatização.

Por raciocínio complementar, se abordamos a circulação nessa visada abrangente, decorre daí que o produto mediático não é o ponto de partida no fluxo. Pode muito bem ser visto como um ponto de chegada, como consequência de uma série de processos, de expectativas, de interesses e de ações que resultam em sua composição como "um objeto para circular" - e que, por sua vez, realimenta o fluxo da circulação (BRAGA, 2012, p.41).

Para Jairo Ferreira (2006) é na circulação que o processo de produção de sentido se efetiva, ou seja, completa seu ciclo. Isso quer dizer que a circulação se estabelece em dois momentos distintos. Primeiro, há um processo de produção do discurso, e depois este discurso passa a ser reconhecido e volta a gerar sentidos, produzindo novos discursos sobre esta produção anterior. Esse reconhecimento se dá a partir dos dispositivos midiáticos e seus protocolos estabelecidos, gerando relações entre as operações de produção e reconhecimento. Há, com isso, uma forte influência do próprio dispositivo que acrescenta sentidos para além dos já previstos. O campo midiático recebe informações, dados, sentidos que são redimensionados dentro de seu próprio campo e, ao chegar aos seus consumidores, já são revestidos de camadas de sentidos atribuídos pelo campo, não mais pelos atores sociais, lugar primeiro de onde partiu a informação.

Conforme Ferreira (2013) a circulação é uma problemática que se destaca nas relações entre processos intermidiáticos (entre dispositivos) e intramidiáticos (no âmago do dispositivo). $\mathrm{O}$ autor acredita que se fortalece a proposição de que a midiatização é uma perspectiva epistemológica, que deve superar os paradigmas de estudos de processo midiáticos desde a produção e consumo, para ser pensada em termos de circulação. "A midiatização se constitui em torno de uma nova problemática: produtores que ocupam posição de consumidores de produtos midiáticos, e de indivíduos-consumidores que passam a ocupar (nas chamadas redes sociais) posição de produtores (configurando o consumo produtivo ou produção consumidora)" (FERREIRA, 2013, p.138-139). 
A partir do que foi exposto até o momento, consideramos que a complexidade da midiatização não repousa mais no âmbito da produção nem da recepção, mas sim da circulação e é a partir dos esforços de pesquisadores em articular hipóteses, problemáticas e construções de abordagens metodológicas que os estudos devem ser direcionados para abordagens empíricas da circulação. Ou seja, o foco dos estudos deve partir da circulação, pois esta está relacionada à onipresença dos dispositivos midiáticos que se interrelacionam e com os quais indivíduos e instituições não midiáticas interagem de múltiplas maneiras.

Apreendemos, com isso, a existência de um novo vínculo na relação entre produção e recepção. Aqueles, detentores da autonomia discursiva e dos modos de construção de suas realidades, operam a partir de sentidos que são postos na circulação oferecendo ao pólo da recepção serviços pelos quais pedem reconhecimento, deslocando-os de uma posição, até então, "amorfa" e "atomizada" para uma posição coprodutora. É, portanto, na circulação em dispositivos que os sentidos se fazem e, através dela, que podemos observar os modos como são produzidos e reconhecidos.

Para Braga (2012), os processos e as consequências desse modo preferencial de circulação, se manifesta concretamente na sociedade, na forma de circuitos - que são culturalmente praticados, são reconhecíveis por seus usuários e podem ser descritos e analisados por pesquisadores. Segundo o autor, para além das relações diretas entre produtor e receptor, importa o fato de que este último faz seguir adiante as reações ao que recebe. Ainda segundo o autor, circuitos são a face empírica específica da circulação e os dispositivos interacionais são a face empírica das interações, moldados pelos contextos e processos institucionais específicos em cujo ambiente ou referência se desenvolvem. Nesse processo, Braga salienta que, a rigor, não é "o produto" que circula - mas encontra um sistema de circulação no qual se viabiliza e ao qual alimenta. Esse produto, entretanto, é um momento particular da circulação porque pode continuar circulando e repercutindo em outros espaços.

Ao refletirmos sobre a circulação diante dessa perspectiva, nos interessa, a seguir, pensar os modos como o leitor coprodutor é construído diante desse cenário, em especial, o das redes sociais digitais. Que tipo de leitor emerge das redes sociais digitais? É com essa preocupação em mente que trabalharemos adiante.

\section{CONSTRUINDO O LEITOR COPRODUTOR NAS REDES SOCIAIS DIGITAIS}


Umberto Eco pela perspectiva da semiótica da interpretação delimita suas experiências de análise a textos narrativos e afirma que "um texto representa uma cadeia de artifícios de expressão que devem ser atualizados pelo destinatário" (ECO, 1987, p.35). Com isso, há uma cooperação entre texto e leitor para que haja interpretação. A instância da produção, ao realizar opções textuais e gráficas, prevê um conjunto de características necessárias para que o texto seja atualizado pelo leitor. A esse conjunto de estratégias, Umberto Eco chama "leitor modelo".

Para organizar a própria estratégia textual, o autor deve referir-se a uma série de competências (expressão mais vasta do que "conhecimento de códigos") que confiram conteúdo às expressões que usa. Ele deve aceitar que o conjunto de competências a que se refere é o mesmo a que se refere o próprio leitor. Por conseguinte, preverá um Leitor-Modelo capaz de cooperar para a atualização textual como ele [...] (ECO, 1987, p.39).

A partir dessa visada, acreditamos que, ao analisar uma matéria jornalística, por exemplo, é possível identificar através de "pistas" deixadas nos enunciados, qual o receptor previsto pela instância da produção, ou seja, qual o "leitor modelo", que não condiz necessariamente com o leitor empírico de fato. De acordo com Eco (1987, p.39), “o texto é um produto cujo destino interpretativo deve fazer parte do próprio mecanismo gerativo. Gerar um texto significa executar uma estratégia de que fazem parte as previsões dos movimentos dos outros". De certo modo, os textos fazem previsões de seus leitores-modelos de diversos modos como a escolha de uma língua, de um tipo de enciclopédia ou de um dado patrimônio lexical e estilístico, por exemplo. O autor ressalta que não se trata de esperar que o leitormodelo exista, mas trabalhar o texto de forma a construí-lo.

Pelo viés da teoria desconstrutivista, Roger Chartier (1996) reflete sobre o leitor e sua prática de leitura propondo o termo "leitor ideal" para identificar aquele para quem um autor destina seu texto, assim como "protocolos de leitura" como uma espécie de um caminho de segurança para que a leitura atinja seus objetivos. Segundo o autor, os protocolos de leitura são uma forma de remontar aos elementos que determinado autor dissemina pelo texto de modo a assegurar ou ao menos indicar a correta interpretação que se deveria dar a ele. "Em outros termos, poder-se-ia dizer que tais protocolos de leitura inscrevem no texto a imagem de um "leitor ideal", cuja competência adequada decodificaria o sentido preciso com que o autor pretendeu" (CHARTIER, 1996, p.10).

Por outro lado, aproximamos ao nosso estudo o olhar da Teoria da Estética da Recepção que dá ênfase ao papel do leitor, situando-o como co-autor do texto, porque esse somente se materializa na recepção. Segundo Iser (1996), o texto fornece pistas a serem 
desvendadas pelo leitor, mas apresenta muitos espaços em branco, para os quais o leitor não encontra respostas e precisa acionar seu imaginário para dar continuidade a essa relação. Assim, o leitor torna-se co-autor do texto porque sua função é descobrir os fios que tecem o texto, sendo um agente que procura significações.

$\mathrm{Na}$ obra "O ato da leitura", Iser (1996) apresenta um esquema com diferentes tipos de leitores: o leitor ideal, o leitor contemporâneo, o arquileitor, o leitor informado, o leitor intencionado e o leitor implícito. O esquema revela que o papel do leitor, inscrito no texto, não pode coincidir com a ficção do leitor, pois é através da ficção do leitor que o autor expõe o mundo do texto ao leitor imaginado. Assim, "o autor produz uma perspectiva complementar que enfatiza a construção perspectivística do texto" (ISER, 1996, p.75). Na ficção do leitor mostra-se a imagem do leitor em que o autor pensava, quando escrevia, e que agora interage com as outras perspectivas do texto. Daí, pode-se deduzir que o papel do leitor designa a atividade de constituição, proporcionada aos receptores dos textos. Conforme Iser (1996, p.75), “o papel do leitor representa sobretudo uma intenção que apenas se realiza através dos atos estimulados no receptor". A partir dessa compreensão, a estrutura do texto e o papel do leitor estão intimamente unidos.

Segundo Chartier (1999), a leitura passa por transformações e o século XVIII foi crucial com o crescimento das produções de livros, transformações dos jornais, multiplicação de bibliotecas e sociedades de leitura, onde era possível ler sem ter que comprar os livros, necessariamente. Há, com isso, uma reorganização da escrita, numa lógica que muda os processos de produção, transmissão e leitura dos textos, redefinindo papéis e funções sociais, pois agora, é possível ser escritor, editor e difusor de um livro tendo um computador como suporte, por exemplo. Chartier (1999) vai explicar que o mundo dos textos eletrônicos remove a rígida limitação imposta à capacidade do leitor de intervir no livro. O objeto impresso impunha sua forma, estrutura e espaços ao leitor e não supunha nenhuma participação material física do leitor. Sua presença no objeto era feita de modo clandestino, ocupando seu manuscrito as margens ou nas páginas em branco. Com o texto eletrônico tudo muda. "Não apenas os leitores podem submeter o texto a uma série de operações (podem indexá-lo, mudálo de um lugar para o outro, decompô-lo e recompô-lo), mas podem também tornar-se coautores" (CHARTIER, 1999, p.27).

A distinção que outrora tivera entre escrever e ler, autor e leitor, dá lugar agora a uma nova realidade: o leitor torna-se um dos possíveis autores de um texto multiautoral, ou no mínimo, o criador de novos textos compostos por fragmentos deslocados de outros autores. 
Nesse cenário, Santaella (2004) destaca três tipos de leitores: o contemplativo, o movente ou errante e o imersivo. A autora ressalta, contudo, que embora haja uma sequencialidade histórica no aparecimento de cada um desses tipos de leitores, isso não significa que um exclui o outro, que o aparecimento de um tipo de leitor leva ao desaparecimento do tipo anterior. O que existe é uma convivência e reciprocidade entre os três tipos de leitores.

O primeiro é o leitor contemplativo/meditativo. Esse tipo de leitor nasce de práticas de leitura de livros a partir do século XII quando intervieram modificações intelectuais e sociais provocadas pela fundação de universidades e o desenvolvimento da instrução entre leigos. “Com a instauração obrigatória do silêncio nas bibliotecas universitárias na Idade Média central, a leitura se fixou definitivamente como um gesto do olho" (SANTAELLA, 2004, p.20). Até então, a articulação vocal que acompanhava o ato da leitura dá lugar ao "ler sem pronunciar em voz alta". Trata-se, pois, de uma experiência moderna, desconhecida durante milênios. O segundo é o leitor moventelfragmentado que nasce junto com a Revolução Industrial e o rápido crescimento das cidades. Os grandes centros urbanos passaram a ter muito mais moradores, em consequência do êxodo rural. Para facilitar o tráfego urbano, foram desenvolvidos sistemas de sinalização, com indicações e sinais. Surgiram o telégrafo, o telefone, as notícias rápidas e imediatas, próprias de cidades com excesso de informação. Segundo Santaella, o mundo público moderno foi se marcando pela lógica do consumo e da moda que estabelece um novo estatuto para a percepção e imaginação. A publicidade também começa a bombardear de informação esse novo leitor da cidade. O terceiro é o leitor imersivo/virtual que nasce na era digital, ou seja, trata-se de um leitor de telas. "O leitor imersivo é obrigatoriamente mais livre na medida em que, sem a liberdade de escolha entre nexos e sem a iniciativa de busca de direções e rotas, a leitura imersiva não se realiza" (SANTAELLA, 2004, p.33). Esse leitor não mais esbarra em signos físicos, materiais e sim, navega numa tela, programa leituras. Esse leitor não segue a sequência de um texto, percorre bibliotecas físicas; é um leitor de prontidão, "que conecta nós e nexos, num roteiro multilinear, multisequencial e labiríntico que ele próprio ajudou a construir ao interagir com os nós entre palavras, imagens, documentação, músicas, vídeo etc" (SANTAELLA, 2004, p.33).

No âmbito do jornalismo em redes sociais, os leitores os leitores coprodutores podem deixar suas marcas sendo possível observar a circulação que se estabelece entre produção e reconhecimento. Essas marcas são analisadas por Palacios (2012) enquanto uma nova forma 
de "Marginália". De maneira ampla, o autor caracteriza a Marginália como qualquer tipo de anotação feita por um leitor em um texto. Enquanto produção de um texto paralelo, ela deve ser entendida na acepção plena de "texto", podendo ser constituída igualmente por símbolos, gráficos, desenhos etc. No que diz respeito à dimensão temporal do fenômeno, as anotações feitas à margem de um texto podem ter uma utilidade imediata para quem as cria, assim como podem igualmente sobreviver a essa temporalidade imediata e extrapolar as intenções originais do seu criador.

$\mathrm{O}$ autor explica que o termo Marginália refere-se a anotações em livros ou manuscritos ${ }^{6}$. No entanto, questiona o termo quando se refere ao contexto jornalístico: "Até que ponto, portanto, pode-se falar em Marginália, quando o objeto de estudo é o jornal, seja ele impresso, seja o ciberjornal de nossos dias?" (PALACIOS, 2012, p.138). Para Palacios, a marginália é um conceito que extrapola o âmbito literário e pode ser de utilidade na análise de marcas deixadas pelos usuários de produtos ciberjornalísticos. O autor observa que a simples quantificação da Marginália, produzida enquanto comentários espontâneos a notícias publicadas, pode constituir um elemento válido para a compreensão de aspectos da recepção jornalística. Segundo o autor, a Marginália jornalística na forma de comentários tem como destinatários outros leitores da notícia e seus autores, sendo assim, um objeto fértil a ser estudado.

É importante também ressaltar-se que ao serem produzidas na forma de comentários espontâneos às notícias publicadas e não como "comentários induzidos", como no caso de fóruns, nos quais é a própria empresa de comunicação que determina os tópicos para debate, os comentários às notícias têm como resultado a produção de uma agenda pública de caráter secundário, filtrada a partir da agenda geral midiática proposta pelo veículo de comunicação. Nesse sentido, mais uma vez é de se assinalar que, independentemente do valor intrínsico dos comentários, o seu próprio volume constitui um elemento de interesse e um objeto de análise (PALACIOS, 2012, p.141).

O autor ainda destaca que a Marginália pode constituir um ferramental de potencial interesse, em relação ao estudo de alguns aspectos da recepção jornalística, especialmente à dimensão comparativa e intercultural da valoração do material disponibilizado para consumo pelas empresas jornalísticas.

\footnotetext{
${ }^{6}$ Segundo Palacios (2012), um exemplo clássico de dupla temporalidade de uma Marginália é encontrado nas Glosas Emilienenses: "anotações em latim, romance e basco, escritas no século XI, provavelmente por um estudante, em um texto latino, na biblioteca do Monastério de San Millán, na Espanha, com a clara intenção de resolver dificuldades de compreensão sintática, morfológica e léxica daquele texto latino [...] a Marginália no manuscrito estava criando o primeiro registro de uma nova língua: o castelhano" (PALACIOS, 2012, p.136).
} 


\section{CONSIDERAÇÕES FINAIS}

Com o exposto até aqui, consideramos que o campo do jornalismo desenvolve-se nesse contexto com a necessidade de manutenção do seu público leitor oferecendo alternativas de conteúdos personalizados e multimidiáticos. Há uma reorganização textual a partir de hipertextos e da multimidialidade que exige dos leitores aptidões para a prática da leitura. Nesse sentido, acreditamos que no cenário das redes sociais digitais há um leitor coprodutor que desenvolve competências e vivencia experiências que são potencializadas com as facilidades das ferramentas tecnológicas. Para Scolari (2008), esta experiência de fruição hipertextual tem construído um tipo de leitor acostumado com a interatividade e com as redes, um usuário "experto" em textualidades fragmentadas com grande capacidade de adaptação a novos entornos de interação. O leitor coprodutor abrange todos os tipos de leitores até aqui citados, dotado de múltiplas habilidades e familiaridade com as lógicas midiáticas. Pois, é contemplativo, movente e imersivo (SANTAELLA, 2004). Também interage, compartilha e participa de processos produtivos.

Acreditamos que o leitor coprodutor no cenário das redes sociais digitais reconhece na facilidade das ferramentas tecnológicas com as quais interage um elemento central para manutenção de seus vínculos e experiências em rede. A midiatização das novas tecnologias convertidas em meio são fundamentais nesse contexto de colaboração e relações individuais desses sujeitos envolvidos em uma rede de contatos compartilhados, reconfigurando seus modos de acesso e consumo, por exemplo. Mais do que vivenciar tais experiências, é fundamental e necessário espalhar/compartilhar aquilo que se experimenta, pois as redes sociais digitais possibilitaram a democratização das competências desses leitores que manejam com desenvoltura linguagens hipertextuais e midiatizadas.

\section{REFERÊNCIAS}

BRAGA, José Luiz. A sociedade enfrenta sua mídia: dispositivos sociais de crítica midiática. São Paulo: Paulus, 2006.

. Circuito versus campos sociais. In: JANOTTI, Jeder; MATTOS, Maria Ângela; JACKS, Nilda (Orgs.). Mediação \& Midiatização. Salvador: EDUFBA, 2012.

CHARTIER, Roger. Práticas de leitura. Trad. Cristiane Nascimento. São Paulo: Estação Liberdade, 1996. 
. As revoluções da leitura no Ocidente. In: ABREU, Márcia (Orgs.). Leitura, História e História da leitura. São Paulo: Mercado de Letras, 1999.

ECO, Umberto. Lector in Fabula. São Paulo: Perspectiva, 1987.

FAUSTO NETO, Antonio. Olhares sobre a recepção através das bordas da circulação. In: XVIII Encontro Anual da Compós, 2009, Belo Horizonte. XVIII Encontro Anual da Compós. Brasília: Compós, 2009.

FERREIRA, Jairo. Dispositivos midiáticos. In: XXIX Congresso Brasileiro de Ciências da Comunicação, 2006, Brasília. Disponível em http://reposcom.portcom.intercom.org/bitstream/1904/20178/1/jairo+ferreira.pdf. Acesso em: 04 maio. 2010.

. Como a circulação direciona os dispositivos, indivíduos e instituições? In: BRAGA, José Luiz; FERREIRA, Jairo; FAUSTO NETO, Antonio; GOMES, Pedro Gilberto (Orgs.). Dez perguntas para a produção de conhecimento em comunicação. São Leopoldo: Unisinos, 2013.

ISER, Wolfgang. O ato da leitura: uma teoria do efeito estético. 2 ed. São Paulo: Editora 34, 1996.

JACKS, Nilda; ESCOSTEGUY, Ana Carolina. Comunicação e recepção. São Paulo: Hacker, 2005.

JACKS, Nilda. Querência: Cultura Regional como Mediação Simbólica. Porto Alegre: UFRGS, 1999.

JACKS, Nilda; SCHMITZ, Daniela. Os meios em Martín-Barbero: antes e depois das mediações. Revista Matrizes, v.12, n.1. São Paulo, 2018.

LOPES, Maria Immacolata Vassalo de. Uma metodologia para a pesquisa das mediações. In:

Coletânea Mídias e Recepção/ 2000. São Leopoldo: Unisinos e Compós, 2000.

MAESTRI, Mariana. Sobre las hiperaudiencias. In: FAUSTO NETO, Antonio; VALDETTARO, Sandra (Org.). Mediatización, sociedad y sentido. Rosário: Departamento de Ciencias de la Comunicación - UNR, 2010.

MARTÍN-BARBERO, Jesús. Dos Meios às Mediações. Comunicação, cultura e hegemonia. Rio de Janeiro: Editora da UFRJ, 2008.

. As formas mestiças da mídia. Entrevistador: Mariluce Moura. Pesquisa Fapesp, p. 10-15, São Paulo, n.163, 2009.

NATANSOHN, Graciela. O que há e o que falta nos estudos sobre recepção e leitura na web? ECompós (Brasília), v. 10, 2007.

PALACIOS, Marcos. Marginália, 'zeitgeist' e memória do tempo presente: os comentários de leitores no ciberjornalismo. In: Brazilian Journalism Research, v.8, n.1, 2012.

PIENIZ, Mônica. Tecnicidade como mediação empírica: a reconfiguração da recepção de telenovela a partir do Twitter. Tese de Doutorado. Porto Alegre: Universidade Federal do Rio Grande do Sul UFRGS. Programa de Pós-Graduação em Comunicação e Informação, 2013.

RE, Facundo Alejandro. La política transmediática. Nuevas formas de participación ciudadana. La Trama de la Comunicación, v. 18, Anuario del Departamento de Ciencias de la Comunicación. 
Facultad de Ciencia Política y Relaciones Internacionales, Universidad Nacional de Rosario. Rosario: UNR Editora, 2014.

RONSINI, Veneza. A perspectiva das mediações de Jesús Martín-Barbero (ou como sujar as mãos na cozinha da pesquisa empírica de recepção). In: XIX Encontro Anual da Compós, 2010, Rio de Janeiro. XIX Encontro Anual da Compós. Rio de Janeiro: Compós, 2010.

SANTAELLA, Lúcia. Navegar no ciberespaço: o perfil cognitivo do leitor imersivo. São Paulo: Paulus, 2004.

SCOLARI, Carlos. Hipermediaciones. Elementos para una teoría de la comunicación digital interactiva. Barcelona: Gedisa, 2008.

VERÓN, Eliseo. Fragmentos de um Tecido. São Leopoldo: Editora Unisinos, 2005.

ZAGO, Gabriela. Recirculação jornalística no twitter: filtro e comentário de notícias por interagentes como uma forma de potencialização da circulação. Dissertação de mestrado. Porto Alegre: Programa de Pós-Graduação em Comunicação e Informação, Fabico/UFRGS, 2011.

Original recebido em: 19 de novembro de 2016

Aceito para publicação em: 19 de setembro de 2017 Doutor em Comunicação e Cultura Contemporâneas (UFBA). Mestre em Ciências da

\section{@ $\odot \Theta \odot$}

Esta obra está licenciado com uma Licença

Creative Commons Atribuição-NãoComercial-CompartilhaIgual 4.0 Internacional 